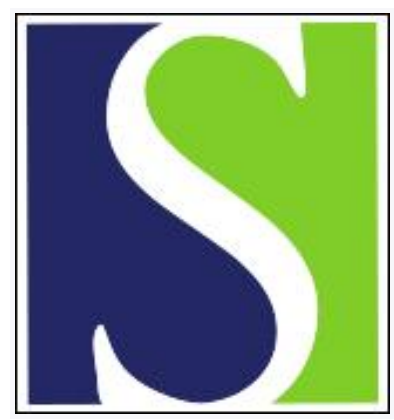

Scand J Work Environ Health 1999;25(2):85-99

https://doi.org/10.5271/sjweh.410

Issue date: Apr 1999

Shift work, risk factors and cardiovascular disease

by Bøggild $H$, Knutsson $A$

The following articles refer to this text: $2001 ; 27(2): 85-86$; 2001;27(2):87-96; 2001;27(2):97-105; 2001;27(3):161-213; 2002;28(1):64-71; 2004;30(2):85-128; 2004;30(2):149-156; 2006;32(3):204-208; 2006;32(3):232-240; 2006;32(6):502-514; 2007;33(1):45-50; 2007;33(6):435-439; 2007;33(6):470-478; 2008;34(1):1-3; 2008;34(1):5-22; 2008;34(3):198-205; 2008;34(3):206-212; SJWEH Supplements 2008;(5):14-21; 2009;35(3):163-179; 2009;35(3):157-161; SJWEH Supplements 2009;(7):24-29; 2010;36(2):109-121; 2010;36(2):96-108; 2010;36(2):150-162; 2010;36(2):81-84; 2011;37(1):77-79; 2011;37(6):533-538; 2012;38(2):171-181; 2014;40(3):287-294; 2015;41(1):84-93; 2015;41(3):259-267; 2015;41(4):356-367; 2015;41(4):347-355; 2017;43(2):117-126; 2017;43(6):569-577; 2018;44(3):229-238; 2018;44(3):251-257; 2018;44(3):225-228; 2019;45(5):465-474; 2020;46(1):1-4; 2020;46(5):508-515; 2022;48(7):511-519

Key terms: cardiovascular disease epidemiology; review; risk factor; work schedule

This article in PubMed: www.ncbi.nlm.nih.gov/pubmed/10360463

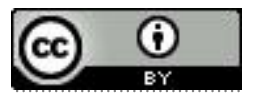




\title{
Shift work, risk factors and cardiovascular disease
}

\author{
by Henrik Bøggild, MD, Anders Knutsson, PhD,
}

\begin{abstract}
Bøggild $H$, Knutsson A. Shift work, risk factors and cardiovascular disease. Scand J Work Environ Health $1999 ; 25(2): 85-99$.

The literature on shift work, morbidity and mortality from cardiovascular disease, and changes in traditional risk factors is reviewed. Seventeen studies have dealt with shift work and cardiovascular disease risk. On balance, shift workers were found to have a $40 \%$ increase in risk. Causal mechanisms of this risk via known cardiovascular risk factors, in relation to circadian rhythms, disturbed sociotemporal patterns, social support, stress, behavior (smoking, diet, alcohol, exercise), and biochemical changes (cholesterol, triglycerides, etc) are discussed. The risk is probably multifactorial, but the literature has focused on the behavior of shift workers and has neglected other possible causal connections. In most studies methodological problems are present; these problems are related to selection bias, exposure classification, outcome classification, and the appropriateness of comparison groups. Suggestions for the direction of future research on this topic are proposed.
\end{abstract}

Key terms cardiovascular disease epidemiology, review, risk factors, work schedule.

Cardiovascular diseases (CVD) are the leading cause of death and disability in most industrialized countries. Medication, operations, and other tertiary preventive actions may have changed the lethality of CVD (1), but rational primary prevention should aim at the causes of CVD and thus reduce the incidence.

The causes of CVD are multifactorial, and during the past 10 years it has been realized that also conditions in the work environment contribute to the etiology of CVD $(2,3)$. A variety of chemical substances has been identified, notably, carbon disulfide and nitroglycerine, but also lead, cobalt, arsenic, solvents, and organophosphates, as causing CVD. The impact of these factors on public health is limited, however, as regards the number of people exposed. More important, from the point of view of society (4), are the psychosocial factors sedentary work, monotonous and other stressful work conditions, passive smoking, and shift work, which have also been identified as occupational risk factors (2). Examining Danish prevalence figures and risk ratios for known chemical and psychosocial factors, Olsen \& Kristensen (5) found the etiologic fraction (the amount of disease that would be prevented if the cause was not present) for psychosocial factors to be around $20 \%$ (sedentary work excluded, as it can be counteracted during leisure time). Dealing with risk factors in the workplace would therefore have a potentially large effect on the prevalence of CVD.

There is no agreement on a definition of shift work in the literature, but it often encompasses work outside the conventional day time and thereby covers fixed evening and night work, roster work, and ordinary 3-shift work. The number of employees working shifts seems to be growing, mainly due to the demand for service around the clock. In Europe approximately $18 \%$ of the work force works at least $25 \%$ of the time at night, and an even larger portion works outside normal workhours (6), a figure consistent with estimates from other industrial countries (7). This characteristic makes shift work one of the most widespread work environment risk factors for CVD.

Knowledge of the links between shift work and CVD are particularly valuable, as shiftwork problems can only be prevented by manipulating these links, not by eliminating the primary exposure, as it is necessary to have a part of the labor force working outside normal workhours due to technical, economic or public service obligations. In contrast to this situation, chemical substances can very

Centre for Working Time Research, Department of Occupational Medicine, Aalborg Regional Hospital, Aalborg, Denmark.

Reprint requests to: Dr Henrik Bøggild, Department of Occupational Medicine (AMK), Aalborg Regional Hospital, Havrevangen, Postbox 561, DK-9100 Aalborg, Denmark. [E-mail: hb@aas.nja.dk] 
often be substituted by less cardiotoxic substances, and high-strain jobs can be changed to lower strain jobs by rearranging the way the work is organized.

This article attempts to elucidate the links between shift work and CVD in order to identify possible points of prevention, first by establishing the evidence of the postulated relationship, then by discussing the routes by which a relation could be transferred, and finally by suggesting future direction for research.

\section{Methods}

The literature was searched in MEDLINE and NIOSHTIC with key words and MESH headings related to shift work, work schedules, cardiovascular risk factors, and cardiovascular disease. The reference lists in published papers were examined and additional studies reviewed. Conference reports from ICOH (International Commission on Occupational Health) scientific committees on shift and night work and on cardiology in occupational health were read. Eventually researchers in the field were contacted.

Studies were included if they were in English or Scandinavian, if they compared shift and day workers or followed shift workers after a change of schedule, and if cardiovascular risk factors or actual CVD end points were reported.

All the studies were judged for methodological quality according to the principles of Kristensen (2) with the time dimension of the study, control of confounders and selection, measures of exposure and outcome, and general design and statistical analysis being taken into account.

\section{Results}

\section{Assessment of the evidence}

The search identified 17 studies on CVD end points in shift workers. Half of these studies had been evaluated by Kristensen in 1989 in the hitherto most comprehensive review (2). On the basis of methodological quality, Kristensen had concluded that ". . . there is a positive correlation between study result and quality so that the better studies in the field consistently find a modestly higher incidence of CVD. . . [p 170]" and regarded the relative risk of 1.4 found by Knutsson et al ( 8 ) to be the most reasonable estimate. The review was updated in 1993 (9), essentially by including 1 additional study, and the conclusion was the same. The literature has also been reviewed by $\AA$ kerstedt et al (10), Orth-Gomér (11), and Wagner (12), whose conclusions have been similar.
The 17 studies are listed in table 1, and the most reasonable estimate for each of the studies has been derived for figure 1. The cross-sectional investigations and a few of the cohort studies reported prevalence figures, and, on the basis of these, odds ratios have been calculated. For the study by Tüchsen (14), we pooled information on all types of shift work and calculated $95 \%$ confidence intervals $(95 \% \mathrm{CI})$ for comparison. As most studies report several risk estimates, assumptions have been made in the selection of estimates for the figure. We have selected the ones that were most reasonable from the point of view that adjustments for confounding factors such as age, gender, nationality, region, other job functions, and social class should be made, while adjustments for cholesterol, smoking, social support, and the like should not be since they are considered mediating factors, combining shift work and CVD, rather than potential confounding factors. We have discussed this view in more detail later in this report. We had to make a compromise in this respect since this distinction was not made in the studies that report either crude estimates or estimates adjusted for all variables that could be regarded as confounders.

Figure 1 shows that the 17 studies lead to very different risk estimates, from an odds ratio of 0.4 to an odds ratio of 3.6. Within these outliers the risk estimates span from 1 to 2. Most of the large studies report a risk estimate around $1.4(8,15-18)$. On the other hand 4 large studies (19-22) failed to find an association, although of roughly the same methodological quality. The figure gives the impression of heterogenic studies (discussed later).

Four investigations attempted to study a dose-response pattern. Knutsson et al (8) found a steep, almost linear increase to 20 years of shift work, for which the relative risk was 2.8. Kawachi et al (17) also found risk to increase, although not in the same magnitude.Tenkanen et al (18) found a weak and statistically insignificant dose-response. Finally, McNamee et al (19) found no dose-response pattern.

Until menopause, women have a lower risk of attracting CVD. This difference can partly be explained by hormonal differences (estrogens) and by differences in lifestyle (23). There are no indications that women should be "immune" to the consequences of shift work (24). The risks of women have been dealt with in the study by Alfredsson et al (25), in which women working in occupations with a large proportion of nondaytime work had an elevated standardized mortality ratio (SMR) of $152(95 \%$ CI 119-191), by Knutsson et al (15), who found an odds ratio of 1.7, and by Kawachi et al (17), who found a relative risk of 1.3 for American nurses. These figures suggest that women have the same risk as men.

As the development of CVD is slow, it would not be suspected that disease would show within a few years of the start of shift work. The study by Knutsson et al (8) 
Table 1. Epidemiologic studies in relation to shift work and morbidity and mortality from cardiovascular disease (CVD) (ex-shift workers not included). $(\mathrm{PR}=$ prevalence rate, $\mathrm{OR}=$ odds ratio, $95 \% \mathrm{Cl}=95 \%$ confidence interval, $\mathrm{AMI}=$ acute myocardial infarction, $\mathrm{SMR}=$ standardized mortality ratio, $R R=$ relative risk, $I C D=$ International Classification of Diseases, $W H O=$ World Health Organization, $S H R=$ standardized hospitalization ratio, $\mathrm{DM}=$ diabetes mellitus, $\mathrm{BMI}=$ body mass index)

\begin{tabular}{|c|c|c|c|c|c|}
\hline Reference ${ }^{\mathrm{a}}$ & Population ${ }^{\mathrm{b}}$ & Exposure / referents & Disease & Controlled confounders & Main results ${ }^{\circ}$ \\
\hline \multicolumn{6}{|c|}{ Cross-sectional studies } \\
\hline $\begin{array}{l}\text { Thiis-Evensen, } \\
1949(106)(x x)\end{array}$ & $\begin{array}{l}1390, \text { of which } 1 / 3 \text { shift } \\
\text { workers, } 388 \text { cases }\end{array}$ & $\begin{array}{l}\text { 3-shift / day work same } \\
\text { factory }\end{array}$ & Mortality, CVD? & & $\begin{array}{l}\text { PR } 34 \% \text { shiff work, } 25 \% \text { day work; } \\
\text { OR } 1.55 \text { (95\% Cl } 1.21-1.97 \text { ) }\end{array}$ \\
\hline $\begin{array}{l}\text { Aanonsen, } 1964 \\
(13)(x x)\end{array}$ & $\begin{array}{l}\text { Men, } 380 \text { shift workers, } \\
345 \text { day workers, } 13 \text { cases }\end{array}$ & $\begin{array}{l}\text { Continuous shift work / day } \\
\text { work }\end{array}$ & $\begin{array}{l}\text { Morbidity, angina } \\
\text { pectoris and AMI }\end{array}$ & Age & $\begin{array}{l}\text { PR: } 1.1 \% \text { shift work, } 2.6 \% \text { day work; } \\
\text { OR }_{t, H} 0.43(95 \% \text { Cl } 0.11-1.59)\end{array}$ \\
\hline $\begin{array}{l}\text { Michel-Briand, } \\
1981(61)(x)\end{array}$ & $\begin{array}{l}\text { Men, retired, } 99 \text { shift work- } \\
\text { ers, } 93 \text { day workers, } 19 \text { cases }\end{array}$ & Shift work? / day work & $\begin{array}{l}\text { Morbidity, angina } \\
\text { pectoris }\end{array}$ & & $\begin{array}{l}\text { PR: } 12.12 \% \text { shift work, } 7.56 \% \\
\text { day work; OR } 1.69(95 \% \mathrm{Cl} 0.64-4.51)\end{array}$ \\
\hline $\begin{array}{l}\text { Koller, } 1983(26) \\
(x x x)\end{array}$ & $\begin{array}{l}\text { Men, blue collar, } 199 \text { shift } \\
\text { workers, } 68 \text { day workers; } \\
\text { about } 45 \text { cases }\end{array}$ & $\begin{array}{l}\text { Rapidly rotating 3-shift/ } \\
\text { day work same factory }\end{array}$ & $\begin{array}{l}\text { Morbidity, ICD } 390- \\
459 \text { (CVD including } \\
\text { varicosis, hypotension) }\end{array}$ & $\begin{array}{l}\text { Age, seniority, } \\
\text { work-conditions? }\end{array}$ & $\begin{array}{l}\text { PR: } 19.9 \% \text { shift work, } 7.4 \% \\
\text { day work; OR } \text { unazij }^{3.17}(95 \% \mathrm{Cl} \\
1.2-8.4)\end{array}$ \\
\hline \multicolumn{6}{|l|}{ Case-referent studies } \\
\hline $\begin{array}{l}\text { Alfredsson, } 1982 \\
(100) 1974-1976 \\
(x \times x)\end{array}$ & $\begin{array}{l}\text { Men, }<65 \text { years, } 334 \text { cases, } \\
882 \text { referents }\end{array}$ & $\begin{array}{l}\text { Aggregated, rotating shift } \\
\text { (changing day and night) } \\
\text { / day (?) }\end{array}$ & $\begin{array}{l}\text { Morbidity and mortality, } \\
\text { AMI (ICD } \\
410.00-410.99)\end{array}$ & $\begin{array}{l}\text { Age, region, smoking } \\
\text { (aggregated) }\end{array}$ & OR $1.25(95 \% \mathrm{Cl} 0.97-1.62)$ \\
\hline $\begin{array}{l}\text { McNamee, } 1996 \\
(19)(x x x) \\
1950-1992\end{array}$ & $\begin{array}{l}\text { Nested case-referent, } \\
\text { among men, <50 years; } \\
467 \text { cases, } 467 \text { referents }\end{array}$ & $\begin{array}{l}1 \text { month 3-shift / day work } \\
\text { same factory }\end{array}$ & $\begin{array}{l}\text { Morbidity and } \\
\text { mortality, AMI }\end{array}$ & $\begin{array}{l}\text { Age, weight, height, } \\
\text { smoking, blood } \\
\text { pressure, job status } \\
\text { (skilled, semi-, unskilled) }\end{array}$ & $\begin{array}{l}\text { OR } 0.9(95 \% \mathrm{Cl} 0.68-1.21) ; \text { no dose- } \\
\text { response }\end{array}$ \\
\hline $\begin{array}{l}\text { Steenland, } 1996 \\
(20)(x x)\end{array}$ & $\begin{array}{l}\text { Nested case-referent, } \\
\text { among men, } 163 \text { cases, } \\
781 \text { referents }\end{array}$ & $\begin{array}{l}\text { Prevalent nighi shift / current } \\
\text { day shift }\end{array}$ & $\begin{array}{l}\text { Mortality CVD } \\
\text { (ICD } 410-414)\end{array}$ & Age, race, plant & $\mathrm{OR}_{\log } 0.64(95 \% \mathrm{Cl} 0.28-1.47)$ \\
\hline $\begin{array}{l}\text { Knutsson, } 1998 \\
(15)(x x x) \\
1992-1994\end{array}$ & $\begin{array}{l}\text { Men: } 1417 \text { cases, } 1808 \\
\text { referents; women: } 589 \\
\text { cases, } 834 \text { referents }\end{array}$ & $\begin{array}{l}\text { Shift or night work last } 5 \text { years } \\
\text { / day work }\end{array}$ & $\begin{array}{l}\text { Morbidity and mor- } \\
\text { tality,AMI }\end{array}$ & $\begin{array}{l}\text { Age, tobacco, } \\
\text { job strain, } \\
\text { education, region }\end{array}$ & $\begin{array}{l}\mathrm{OR}_{\mathrm{ftg}} \text { men: } 1.3(95 \% \mathrm{Cl} 1.1- \\
1.6) ; \text { women: } 1.3(95 \% \mathrm{Cl} \\
0.9-1.8)\end{array}$ \\
\hline \multicolumn{6}{|l|}{ Cohort studies } \\
\hline $\begin{array}{l}\text { Taylor, } 1972(21) \\
(x x) 1956-1968\end{array}$ & $\begin{array}{l}\text { Men, }>52 \text { years, } 4188 \text { shift } \\
\text { workers, } 3860 \text { day } \\
\text { workers, } 540 \text { cases }\end{array}$ & $\begin{array}{l}>10 \text { years shift work in } 10 \\
\text { factories } />10 \text { years of day- } \\
\text { work (less than } 1 / 2 \text { year of shift } \\
\text { work), compared to population }\end{array}$ & $\begin{array}{l}\text { Mortality, AMI (ICD } \\
400-468 \text { ) }\end{array}$ & Age & $\begin{array}{l}\text { SMR } 102 \text { shift work, } 92 \\
\text { day work; } R R_{\text {innadj }} 1.00 \\
\text { (95\% CI } 0.84-1.18 \text { ) }\end{array}$ \\
\hline $\begin{array}{l}\text { Angersbach } 1980 \\
(107)(x x) 1966- \\
1977\end{array}$ & $\begin{array}{l}370 \text { shift workers, } 270 \\
\text { day workers, } 102 \text { cases }\end{array}$ & $\begin{array}{l}>1 / 2 \text { year continuous } 12 \text {-hour } \\
\text { rotating shift work } />1 / 2 \text { year } \\
\text { of noncontinuous day work }\end{array}$ & $\begin{array}{l}\text { Morbidity, AMI, ar- } \\
\text { rhythmia, hypertension } \\
\text { etc (from sick leaves) }\end{array}$ & . & $\begin{array}{l}\text { Incidence } 16.8 \% \text { shift work, } 14.8 \% \\
\text { day work; } R R 1.13(95 \% \mathrm{Cl} \\
0.79-1.63)\end{array}$ \\
\hline $\begin{array}{l}\text { Alfredsson, } 1985 \\
(25)(x x x) 1976\end{array}$ & $\begin{array}{l}\text { Men and women, } 20-64 \\
\text { years, } 985096,1201 \text { cases }\end{array}$ & $\begin{array}{l}\text { Aggregated (other than } \\
\text { daytime) / day time }\end{array}$ & $\begin{array}{l}\text { Morbidity, AMI (ICD } \\
410-410.99)\end{array}$ & Age & $\begin{array}{l}\text { SMR men: } 115 \text { (95\% Cl 104-126); } \\
\text { women: } 152(95 \% \text { Cl 119-191) }\end{array}$ \\
\hline $\begin{array}{l}\text { Knutsson, } 1986 \\
\text { (8) }(x x x x) \\
1968-1983\end{array}$ & $\begin{array}{l}\text { Men, }>20 \text { years, } 394 \text { shift } \\
\text { workers, } 110 \text { day workers, } \\
43 \text { cases }\end{array}$ & $\begin{array}{l}>6 \text {-month rotating } 3 \text {-shift } \\
\text { (process operators) / day work } \\
\text { (maintenance) at same factory }\end{array}$ & $\begin{array}{l}\text { Morbidity and mortal- } \\
\text { ity, angina pectoris } \\
\text { and AMI (WHO criteria) }\end{array}$ & $\begin{array}{l}\text { Age, tobacco, family } \\
\text { status }\end{array}$ & $\begin{array}{l}\mathrm{RR} 1.4(95 \% \mathrm{Cl} 0.7-2.7) \text {, dose- } \\
\text { response for work exposure } 2-20 \\
\text { years; } O R_{\text {fog }} 1.53(95 \% \mathrm{Cl} 0.65-3.64)\end{array}$ \\
\hline $\begin{array}{l}\text { Åkerstedt, } 1987 \\
(16)(x x x) 1976\end{array}$ & $\begin{array}{l}\text { Men, 20-64 years, } 1059 \\
\text { cases }\end{array}$ & $\begin{array}{l}\text { Aggregated (including night) / } \\
\text { day }\end{array}$ & $\begin{array}{l}\text { Morbidity, AMI (ICD } \\
410-410.99 \text { ), is- } \\
\text { chemic heart disease } \\
\text { (ICD 410-414) }\end{array}$ & $\begin{array}{l}\text { Age, work condi- } \\
\text { tions, cohabitation, } \\
\text { children, region, } \\
\text { nationality }\end{array}$ & $\begin{array}{l}\text { SMR AMl: } 148 \text { (95\% Cl 112-191); } \\
\text { ischemic heart disease: } 128(95 \% \mathrm{Cl} \\
\text { 103-158) }\end{array}$ \\
\hline $\begin{array}{l}\text { Tüchsen, } 1993 \\
\text { (14) }(x x x) 1981\end{array}$ & $\begin{array}{l}\text { Men, } 20 \text { - } 59 \text { years, } \\
1293888,5966 \text { cases }\end{array}$ & $\begin{array}{l}\text { Aggregated (night and morn- } \\
\text { ing,late evening, 24-hour work, } \\
\text { other irregular) } \\
\text { / day work }\end{array}$ & $\begin{array}{l}\text { Morbidity, ischemic } \\
\text { heart disease (ICD8 } \\
\text { 410-414) }\end{array}$ & Age & $\begin{array}{l}\text { SHR, group 1: } 193(90 \% \mathrm{Cl} 158-236) \text {, } \\
\text { group 2: } 215(90 \% \mathrm{Cl} 192-240 \text {, group } \\
\text { 3: } 168(90 \% \mathrm{Cl} 151-185) \text {, group 4: } \\
172(90 \% \mathrm{Cl} 166-182) ; \text { overall SHR } \\
178(95 \% \mathrm{Cl} 170-186)\end{array}$ \\
\hline $\begin{array}{l}\text { Kawachi, } 1995 \\
(17)(x x x) 1988- \\
1992\end{array}$ & $\begin{array}{l}\text { Female nurses, } 42-67 \\
\text { years, } 46956 \text { shift workers, } \\
32153 \text { day workers, } \\
292 \text { cases }\end{array}$ & $\begin{array}{l}>1 \text { year of }>3 \text { nights } \\
\text { a month (rotating) / day } \\
\text { (including fixed evening } \\
\text { and night?) }\end{array}$ & $\begin{array}{l}\text { Morbidity and mor- } \\
\text { tality, AMI }\end{array}$ & $\begin{array}{l}\text { Age, smoking, hyper- } \\
\text { tension, DM, hypercho- } \\
\text { lesterolemia, use of post- } \\
\text { menopausal hormones, } \\
\text { alcohol, physical activity, } \\
\text { genetics, use of aspirin } \\
\text { and vitamin E, } \\
\text { male education }\end{array}$ & $\begin{array}{l}\text { RR } 1.31 \text { (95\% Cl 1.02-1.68), } \\
\text { dose-response }\end{array}$ \\
\hline $\begin{array}{l}\text { Tenkanen, } 1997 \\
(18), 1987-1993 \\
(x x x)\end{array}$ & $\begin{array}{l}\text { Men, } 40-55 \text { years, } 564 \\
\text { shift workers, } 511 \text { day } \\
\text { workers, ? cases }\end{array}$ & $\begin{array}{l}\text { Prevalent, mainly } \\
\text { continuous, slowly } \\
\text { rotating 3-shift in } 5 \\
\text { industrial companies / } \\
\text { day }\end{array}$ & $\begin{array}{l}\text { Morbidity and mor- } \\
\text { tality, ischemic heart } \\
\text { disease (ICD9 } 410 \\
\text {-414) }\end{array}$ & $\begin{array}{l}\text { Age, smoking, BMI, } \\
\text { spare-time physical } \\
\text { activity, alcohol, blood } \\
\text { pressure,lipid, job strain; } \\
\text { restricted to blue collar, } \\
\text { certain occupations }\end{array}$ & $\begin{array}{l}\text { RR } 1.33 \text { (95\% CI 0.89-1.99), } \\
\text { "weak dose-response" }\end{array}$ \\
\hline $\begin{array}{l}\text { Bøggild, } 1998(22) \\
1971-1993(x x x)\end{array}$ & $\begin{array}{l}\text { Men, } 40-59 \text { years, } 1123 \\
\text { shift workers, } 4084 \text { day } \\
\text { workers, } 1006 \text { cases }\end{array}$ & $\begin{array}{l}\text { Prevalent work on shift or } \\
\text { irregular work hours in } 14 \\
\text { companies/ day work }\end{array}$ & $\begin{array}{l}\text { Morbidity and mortali- } \\
\text { ty, ischemic heart } \\
\text { disease (ICD8 } \\
410-414)\end{array}$ & $\begin{array}{l}\text { Age, social class, sleep, } \\
\text { smoking, weight, height, } \\
\text { fitness value }\end{array}$ & $\operatorname{RR} 0.9(95 \% \mathrm{Cl} 0.7-1.1)$ \\
\hline
\end{tabular}

: Overall quality of study, based on Kristensen (2) also given (range from $x$ to $x x x x$ ), as well as the period of registration where available.

' Gender, age, number [exposed, unexposed, cases (cohort) or cases and referents (case-referent)]

- Selected results; reanalyzed figures in italics. 


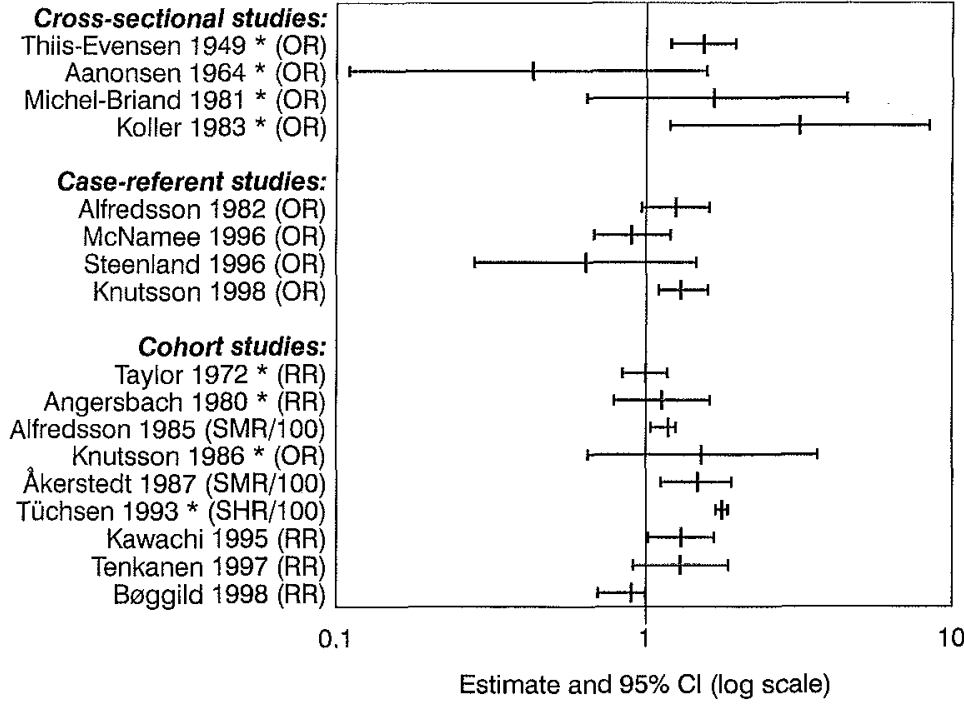

Figure 1. Epidemiologic studies on the relation between shift work and cardiovascular diseases (CVD) among men - selected estimates. (See the text and table 7.) (* indicates reanalyzed materials) found the risk to increase after 2 years of shift work, but they did not include information on lag time, although they argued that no differences were seen with different lag time spans. McNamee et al (19) have also analyzed data with different lag times and found no differences. Likewise it could be expected that leaving shift work would lower the risk of CVD in subsequent years and eventually lead to a risk resembling that of unexposed populations, as has been shown in the case of smoking cessation. Several studies on ex-shift workers have been carried out $(21,26)$, but none of them have examined the effect of prolonged exposure-free periods on the subsequent risk.

The diversity of studies renders a meta-analysis problematic, but the most reasonable risk estimate seems still to be the relative risk of 1.4 derived from the hitherto methodologically most convincing study by Knutsson et al (8), whose results are supported by the demonstration of a dose-response and an equal risk for both genders.

\section{Causal mechanisms}

The next section examines the possible biological pathways linking shift work with CVD. The term risk factor is, in general, used to designate factors that link the environment to CVD and that precede disease, predict disease strongly and are dose-related from study to study independently of other contributors (27). Thus far, more than 250 risk indicators have been identified (28); however in this article we have dealt with only a minority of them and have focused on changeable factors (smoking, dieting, social support) rather than on inherent ones (age, gender, familial hypercholesterolemia, a genetic disease) (29). Furthermore, we have divided the risk factors into external risk factors and biomarkers that designate the body response to external risk factors.

The following section of the article is based on a model originally proposed by Knutsson (30). It identifies 3 different, but interrelated pathways that lead from shift work to disease - mismatch of circadian rhythms, social disruption and behavioral changes. A 4th pathway not originally in the model consists of changes in biomarkers. The model is used as a mental aid in discussions of the potential influence of traditionally accepted risk factors.

\section{Mismatch between circadian rhythms and sleep}

Shift work leads to changes in circadian rhythms of the body and thus causes an imbalance in the homeostasis of the body that leads to internal desynchronization, the mismatch of related circadian rhythms. A mismatch of circadian rhythms may be of importance to nutrition, as both enzymatic activity and stomach emptying are circadian rhythmic and may be desynchronized from the meals of shift workers. One study found that cholesterol correlated with the distribution of meals and that cholesterol levels were higher when a larger proportion of the diet was ingested at night (31). Shift workers often change the distribution of their food intake, and, therefore, changes can occur in the concentrations of their biomarkers.

The mismatch of rhythms is known also to be important in relation to the manifestation of disease. Several studies have confirmed the well-known clinical experience that the onset of both myocardial infarction and angina pectoris is more common in the early morning. This chronobiological rhythm has been explained by a mismatch between oxygen supply and demand at awakening. The mismatch may give rise to a precipitation of myocardial infarction in vulnerable persons if the circadian rhythm of oxygen supply does not adjust promptly to the changed demand of night work. There are no studies looking at the hourly distribution of myocardial infarction among shift workers, but a peak on Mondays for the working population as a whole suggests that rising for 
work is a risk factor (32), and a secondary peak in the late afternoon has been proposed to stem from a person's waking from their day sleep (33).

An increased number of ventricular extrasystoles in people who work nights has likewise been explained by desynchronized rhythms (34).

Shift workers are known to sleep less than day workers and to be more fatigued (35). There is limited knowledge on a possible relationship between lack of sleep and CVD. Sleep apnea syndrome is a risk factor for CVD (36), but no studies have looked at the relationship between shift work and sleep apnea syndrome. The concept of "vital exhaustion" $(37,38)$, in which exhaustion is a risk factor for later CVD has not been studied among shift workers either. Not only can stress lead to sleep problems, lack of sleep has also been described as a stressor (39) and through this action can be regarded as a potential risk factor. The stress of sleep deprivation is discussed later in this article. In conclusion, exhaustion, sleep apnea, and exposure to circadian mismatch may be risk factors, but no literature links shift work with them.

\section{Disturbed sociotemporal patterns, social support and stress}

Another well-known consequence of shift work is problems in family life, as the workhours interfere with social activities, reduce the time available for both family and recreation, and potentially lead to social isolation and subsequent stress.

Social support has emerged as a risk factor for CVD (40), and, since one of the main causes of stress among shift workers is problems with the relationship between family life and worklife, social support could be of importance in the interaction between shift work and CVD. The risk is individually tied to the actual family pattern and to the dynamics of familial interactions and, therefore, is difficult to measure. No studies have attempted to examine the social support of shift working families in relation to the occurrence of CVD among shift workers.

Stress is probably one of the key elements in the relationship between shift work and disease. The definition of stress varies, but in general it can be anticipated as "a particular relationship between the person and the environment that is appraised by the person as taxing or exceeding his or her resources and endangering his or her well-being [p 19]" (41). This definition implies that people respond differently to similar stressors. In occupational settings stress has been defined according to demand and decision latitude, person-environment misfit, and ef fort-reward imbalance. Stress defined according to Lazarus has been related to changes in cholesterol (42), but not to CVD end points. The strain model and the effortreward imbalance model are both associated with myocardial infarction $(43,44)$, but it is unclear whether these models adequately measure the specific kind of stress that is associated with shift work [in relation to conflicts between roles in family and worklife and the physiological desynchronization of circadian rhythms possibly leading to sleep disturbances (45-51)].

The possible mechanisms linking stressful experiences to psychophysiological changes have been extensively studied (52), but only 1 investigation (53) has examined the relationship between shift work, stress, and cardiovascular risk factors. This study measured glycated hemoglobin as a marker of catabolic drive and found higher values for shift workers than for day workers. The shift workers were, however, also subject to other stressors in the work environment (eg, noise and overtime).

Both a possible effect of social support and a possible effect of stress on shift workers' risk of CVD have received remarkably little attention in the literature.

\section{Behavioral changes}

Both as a consequence of stress, eventually acting through attempts to cope with the stressors of shift work, and as a direct consequence of poor work conditions in general (closed canteens at night), the life-style of shift workers and day-working colleagues may differ. Studies on the behavior of shift and day workers are presented in table 2.

Being one of the most important risk factors for CVD, tobacco use may constitute an important part of the path between shift work and CVD, providing that shift workers smoke more than their day-working counterparts. Six (54-59) of 13 cross-sectional studies found that shift workers smoke significantly more than day-working referents (table 2). One study (60) found that shift workers smoked less than day workers, and the rest did not find any differences $(48,61-64)$. In the 2 cohort studies for which characteristics can be evaluated $(8,22)$, shift workers smoked significantly more than day workers at the beginning of the study. In the relative short prospective studies (up to a year of follow-up) of new shift workers or following changes in shift schedules, the shift workers did not tend to start smoking or change smoking habits $(65,66)$. This finding suggests that the smoking habits of shift workers change slowly. In the 7 "positive" studies the quantitative differences were $10-40 \%$. In none of the studies that attempted to control for tobacco consumption did smoking habits in full explain the increased risk.

Use of alcohol in a moderate amount has been found to be protective from CVD (67). In 10 studies alcohol consumption was addressed. Six cross-sectional $(56,58$, $60-62,64)$ and 1 prospective study $(68)$ did not find any difference between day and shift workers, while 1 study found a smaller $(63)$ and 2 studies $(22,48)$ a larger alcohol consumption among shift workers. One of the studies measured gamma glutamyl transferase, aspartate 
Table 2. Studies on life-style-related risk factors among shift workers. If not otherwise stated, the first value is shift worker, the other day worker. Statistically significant results are marked in italics. If results are stated without quoting the actual numbers " + " or " 0 " is used for statistically significant and nonsignificant differences.

\begin{tabular}{|c|c|c|c|c|c|c|}
\hline Reference ${ }^{a}$ & Persons & $\begin{array}{l}\text { Tobacco smokers } \\
(\%)\end{array}$ & $\begin{array}{l}\text { Alcohol users } \\
(\%)\end{array}$ & Diet & Exercise & $\begin{array}{l}\text { Body mass index } \\
\mathrm{kg} / \mathrm{m}^{2}\end{array}$ \\
\hline \multicolumn{7}{|c|}{ Cross-sectional and cohort study base line } \\
\hline Theile, $1976(54)(x)$ & $\begin{array}{l}1291 \text { shift workers, } \\
5224 \text { day workers }\end{array}$ & $64.9 / 54.8$ & . & . & . & Weight: $76.6 / 74.7$ \\
\hline $\begin{array}{l}\text { Michel-Briand, } 1986 \\
(61)(x)\end{array}$ & $\begin{array}{l}99 \text { shift workers, } \\
93 \text { day workers }\end{array}$ & $51 / 53$ & 0 & . & . & \\
\hline Gordon, $1986(48)(x)$ & $\begin{array}{l}1661 \text { shift workers, } \\
\text { ? day work + fixed } \\
\text { night workers }\end{array}$ & 0 & + & . & . & . \\
\hline Knutsson, $1986(8)$ (xxx) & $\begin{array}{l}394 \text { shift workers, } \\
110 \text { day workers }\end{array}$ & $74 / 50$ & . & . & . & . \\
\hline $\begin{array}{l}\text { De Backer, } 1987 \\
(62)(x x)\end{array}$ & $\begin{array}{l}243 \text { shift workers, } \\
401 \text { day workers }\end{array}$ & $48 / 40$ & $20.8 / 20.7$ & 0 & 0 & $24.9 / 24.7$ \\
\hline $\begin{array}{l}\text { Knutsson, } 1988 \\
(55)(x \times x)\end{array}$ & $\begin{array}{l}361 \text { shift workers, } \\
240 \text { day workers }\end{array}$ & $54 / 39$ & . & . & . & $25.8 / 25.9$ \\
\hline $\begin{array}{l}\text { Knutsson, } 1989 \\
(56)(x \times x)\end{array}$ & $\begin{array}{l}329 \text { shift workers, } \\
233 \text { day workers }\end{array}$ & $43 / 33$ & 0 & . & . & . \\
\hline Cesana, $1990(57)(x)$ & $\begin{array}{l}150 \text { shift workers, } \\
150 \text { day workers }\end{array}$ & + & . & . & . & 0 \\
\hline Bursey, $1990(74)(x)$ & $\begin{array}{l}57 \text { shift workers, } \\
57 \text { day workers }\end{array}$ & Matched & . & . & . & 0 \\
\hline Costa, $1990(60)(x)$ & $\begin{array}{l}158 \text { shift workers, } \\
44 \text { day workers }\end{array}$ & $22 / 39$ & $49.3 / 48.6$ & . & $74.1 / 81.8$ & $26.1 / 25.6$ \\
\hline Romon, 1992 (63) (xxx) & $\begin{array}{l}73 \text { shift workers, } \\
73 \text { day workers }\end{array}$ & $\begin{array}{l}\text { Cigarettes/day } \\
15.4 / 13.9\end{array}$ & $\begin{array}{l}\text { Grams/day: } \\
9.3 / 15.6\end{array}$ & $\begin{array}{l}0 \text { (energy, } \\
\text { carbohydrates, fat) }\end{array}$ & Matched & $24.6 / 24.7$ \\
\hline $\begin{array}{l}\text { Lasfargues, } 1996 \\
(58)(x x)\end{array}$ & $\begin{array}{l}1400 \text { shift workers, } \\
1400 \text { day workers }\end{array}$ & $\begin{array}{l}\text { Men: } 46.2 / 38.4 \\
\text { women: } 41.9 / 32.3\end{array}$ & $\begin{array}{l}\text { Grams/day: } \\
\text { men: } 23 / 25 \text {, } \\
\text { women: } 2 / 5\end{array}$ & $\begin{array}{l}\text { More water and } \\
\text { milk, missing meals }\end{array}$ & $\begin{array}{l}>1 \text { hour/day: } \\
58.9 / 55.9 \\
\text { women: } 50.7 / 26.7\end{array}$ & $\begin{array}{l}\text { Men: } 25.3 / 24.8 \\
\text { women: } 23.7 / 22.7\end{array}$ \\
\hline $\begin{array}{l}\text { Nakamura et al, } 1997 \\
\text { (64) (xxx) }\end{array}$ & $\begin{array}{l}33 \text { shift workers, } \\
239 \text { day workers }\end{array}$ & $76.9 / 71.6$ & Everyday: $54 / 40$ & . & Never: $69.2 / 50.2$ & $23.4 / 23.0$ \\
\hline $\begin{array}{l}\text { Knutsson, } 1998 \\
(59)(x x)\end{array}$ & $\begin{array}{l}906 \text { shift workers, } \\
4514 \text { day workers }\end{array}$ & $\begin{array}{l}\text { Men: } 24 / 22, \\
\text { women: } 31 / 27\end{array}$ & . & . & . & . \\
\hline Bøggild, 1998 (22) (xx) & $\begin{array}{l}1123 \text { shift workers, } \\
4084 \text { day workers }\end{array}$ & $76.1 / 71.0$ & $\begin{array}{l}\text { Grams/day among } \\
\text { users: } 17.7 / 16.8\end{array}$ & . & $\begin{array}{l}\text { Fittness value }\left(\mathrm{VO}_{2}\right) \text { : } \\
33.4 / 32.7\end{array}$ & $\begin{array}{l}\text { Weight }(\mathrm{kg}) \text { : } \\
78.0 / 76.9\end{array}$ \\
\hline \multicolumn{7}{|l|}{ Prospective studies } \\
\hline Theorell, 1976 (68) (xxx) & $\begin{array}{l}33 \text { shift workers, } \\
\text { own referents }\end{array}$ & 0 & 0 & 0 & 0 & . \\
\hline $\begin{array}{l}\text { Orth-Gomér, } 1983 \\
(65)(x x x)\end{array}$ & $\begin{array}{l}46 \text { shift workers, } \\
\text { clockwise and } \\
\text { counterclockwise, } \\
\text { own referents }\end{array}$ & $\begin{array}{l}4.7 \text { (cigarettes/ } \\
\text { shift)/ } 4.4\end{array}$ & . & . & . & 0 \\
\hline $\begin{array}{l}\text { Knutsson, } 1990 \\
(66)(x x)\end{array}$ & $\begin{array}{l}12 \text { shift workers, } \\
13 \text { day workers }\end{array}$ & 0 & . & $+($ dietary fibers $)$ & . & . \\
\hline $\begin{array}{l}\text { Lennernäs, } 1994 \\
\text { (31) (xxx) }\end{array}$ & $\begin{array}{l}22 \text { shift workers, } \\
\text { own referents }\end{array}$ & . & . & $+($ distribution $)$ & . & . \\
\hline
\end{tabular}

a Overall quality of study, based on Kristensen (2) is given (range from $x$ to $x x x x x$ ).

aminotransferase, and alanine aminotransferase as markers of alcohol consumption without finding any difference (56) between the day and shift workers.

Especially the ratio between saturated and polyunsaturated fat in the diet has been established as a risk factor for CVD, but also the amount of energy coming from fat is an independent risk (69). The diet of shift workers has been examined in 13 studies, recently evaluated by Lennernäs in her dissertation (70). The studies on diet have demonstrated only few differences between shift and day workers with regard to nutritional intake, but changes in meal frequency and the timing of meal intake among shift workers were reported in several studies. Six studies correlated nutritional data with biomarkers for CVD. In 2 cross-sectional studies there were no differences between shift and day workers with respect to energy, carbohydrates, fat, or protein $(62,63)$, while 1 study found that shift workers drink more milk and water, and they miss meals (58), all without concurrent differences in biomarkers. In the prospective studies a more frequent use of snacks with a high amount of single carbohydrates at night (66) and a change in distribution was seen $(31,71)$. One prospective study did not find dietary differences (68) between day and night workers. The change in meal 
distribution was associated with changes in cholesterol (31), which was seen as a result of circadian desynchronization of uptake and metabolism.

Regular exercise is protective from CVD (72). In 3 studies $(58,60,62)$ no differences in exercise habits were found, while 1 study found (58) that a higher proportion of female shift workers used more than 1 hour a day to exercise. One prospective study found no differences in exercise patterns between working a day shift and working a night shift (68), one found a higher proportion of persons doing exercise among day workers (64), while a cohort study found the shift workers to have higher fitness values at the beginning of the study (22).

Differences in nutrition and exercise habits eventually lead to differences in weight, and moderate overweight has been found to be a risk factor for CVD (73). In 8 studies of shift workers $(55,57,60,62-65,74)$, in which the question has been addressed, no difference in either weight or body mass index was reported. Two studies found that shift workers were heavier than day workers $(22,58)$. An interesting but unsettled issue has recently been raised by Nakamura et al (64), who found that, although the body mass index was the same for day and shift workers, shift workers had more centrally disposed adipose tissue, which has been found to be a risk factor of CVD.

\section{Biological mechanisms (biomarkers)}

The evolution of CVD is slow and probably consists of 2 partly separated processes, a slowly atherosclerotic process and later thrombosis $(29,75)$. It is assumed that manifest illness is preceded by changes in the concentration of markers of these processes, and they are thus regarded as biomarkers of subclinical disease (76). The best examined markers are cholesterol and other lipids [triglyceride and apolipoproteins, fraction A and B (Apo A, Apo B)] $(29,77,78)$, reflecting atherosclerosis. Other markers mirror the coagulation and fibrinolytic processes, among these thrombocytes, fibrinogen (79), factor VIIc $(80,81)$, the fibrinolysis products tissue plasminogen activator (t-PA), tissue plasminogen activator inhibitor (t-PAI), and complement (75), all of which have been found to be independent risk factors. Glycated hemoglobin ( $\mathrm{HbA} 1 \mathrm{c})$, which reflects glucose metabolism and thus acts as a biomarker of stress $(82,83)$, has also been shown to be an established risk factor for CVD (84). High blood pressure and electrocardiographic signs of hypertrophy are also established risk factors, which have been regarded as biomarkers in this review.

The literature search revealed 27 studies on biomarkers of CVD in shift workers. Most of the studies are presented in table 3 .

In 10 of 16 investigations cholesterol levels did not differ between day and shift workers (table 3) $(55,57$,
$60,62,63,65,74,85-87)$, while 5 studies found higher values for shift workers or higher values related to different organizations of shift work $(31,54,64,66,68)$. One study found lower values among male shift workers, but no differences among women (58). In $3(31,66$, $68)$ of $6(31,65,66,68,86,87)$ prospective studies, significant changes in cholesterol were found. The magnitude of change in studies with significant differences was between $3 \%$ and $20 \%$. Differences in the high-density lipoprotein (HDL) and low-density lipoprotein (LDL) fractions of cholesterol were assessed in 3 cross-sectional studies $(60,62,63)$, and no statistically significant difference was found. In 1 longitudinal study (31) a correlation between diet and the LDL:HDL ratio was found, and in another there was a decrease in the LDL:HDL ratio at the change to fewer night shifts in a row (87), while 1 study did not find changes (86).

Apolipoprotein has been measured at the change from day to shift work. A statistically significant increase in ApoB and, accordingly, an increase in the ApoB:ApoA1 ratio (66) was found. In a cross-sectional study (88) no difference was found between shift and day workers.

Triglyceride has been measured in 12 studies $(54,55$, $57,58,60,62-66,86,87)$, among which 4 found statistically higher values among shift workers $(55,58,63,65)$. Orth-Gomér (65) found higher values for counter clockwise than clockwise rotation (from day to evening to night shift rather than from day to night to evening shift).

Plasminogen activator and tissue plasminogen activator inhibitor ( $t-P A$ and $t-P A I)$ were measured (89) as indicators for the fibrinolytic system and were found to include both a phase shift and a reduction in amplitude in shift workers. This finding suggests that the dissolution of thrombi could be slower due to the lower activity. One study (85) found higher fibrinogen levels among shift workers than among day workers.

In $9(22,54,55,57,58,63,64,74,85)$ of 19 studies on blood pressure or hypertension, there were no differences between day and shift workers. Two studies found more hypertensive subjects among the day workers (61, 90 ), one found a lower (91) and one (60) found a higher diastolic pressure among shift workers, and one a higher (65) and one a lower systolic pressure (92). Three studies have measured 24-hour blood pressure (93-95), of which one found (94) that the high plateau of both systolic and diastolic pressures in the nightshift workers were longer, although no difference in the mean pressure was found. The differences between the shift and day workers were small [maximum $3 \mathrm{~mm} \mathrm{Hg}(0.40 \mathrm{kPa})$ higher diastolic blood pressure]. Such differences have been associated with a $10 \%$ higher risk of CVD (77), and this finding suggests that changes in blood pressure were not solely responsible for the relation. A German review (96) concluded that there is no relationship between shift work and higher risk of hypertension. 
Table 3. Studies on biomarkers for cardiovascular diseases among shift workers. If not otherwise stated, the first value is shift worker, the other day worker. Statistically significant results are marked in italics. If the results are stated without the actual numbers being quoted, " + " and "." have been used as statistically significant positive and negative associations, and " 0 " as nonsignificant changes. $(\mathrm{LDL}=$ low-density lipoprotein, $\mathrm{HDL}=$ high-density lipoprotein, $\mathrm{S}=$ mean systolic pressure, $\mathrm{D}=$ mean diastolic pressure, $\mathrm{HbA1C}=$ glycoted hemoglobin, ${ }^{*}=$ circadian rhythms varied between shift and day workers, $24 \mathrm{~h}=24$-hour ambulatory pressure, t-PAl $=$ tissue plasmingen activator inhibitor)

\begin{tabular}{|c|c|c|c|c|c|c|c|}
\hline Referencea & Persons & $\begin{array}{l}\text { Cholesterol } \\
(\mathrm{mmol} / \mathrm{l})\end{array}$ & $\begin{array}{l}\mathrm{LDL} / \mathrm{HDL}- \\
\text { cholesterol } \\
(\mathrm{mmol} / \mathrm{l})\end{array}$ & $\begin{array}{l}\text { Triglycerides } \\
(\mathrm{mmol} / \mathrm{l})\end{array}$ & $\begin{array}{l}\text { Apo-protein } \\
\text { (mmol/l) }\end{array}$ & Blood pressure & $\begin{array}{l}\text { Other } \\
\text { biomarkers }\end{array}$ \\
\hline \multicolumn{8}{|c|}{ Cross sectional and baseline cohort studies } \\
\hline $\begin{array}{l}\text { Thelle, } 1976 \\
(54)(x)\end{array}$ & $\begin{array}{l}1291 \text { shift workers, } \\
5224 \text { day workers }\end{array}$ & $6.79 / 6.58$ & . & $1.48 / 1.41$ & . & $\begin{array}{l}\text { S: } 127.2 / 126.3 \\
\text { D: } 79.1 / 77.5\end{array}$ & . \\
\hline $\begin{array}{l}\text { Fouriaud, } 1984 \\
(92)(x)\end{array}$ & $\begin{array}{l}94 \text { shift workers, } \\
2640 \text { day workers } \\
\text { (women) }\end{array}$ & . & . & . & . & S: $125.3 / 130.1$ & . \\
\hline $\begin{array}{l}\text { Cesana, } 1985 \\
(53)(x)\end{array}$ & $\begin{array}{l}100 \text { shift workers, } \\
200 \text { day workers }\end{array}$ & . & . & . & . & . & HbAtc: $8.04 / 7.40$ \\
\hline $\begin{array}{l}\text { De Backer, } 1987 \\
(62)(x x)\end{array}$ & $\begin{array}{l}243 \text { shift workers, } \\
401 \text { day workers }\end{array}$ & $5.21 / 5.28$ & Ratio: $32 / 32$ & $4.7 / 4.7$ & . & . & . \\
\hline $\begin{array}{l}\text { Knutsson, } 1988 \\
(55)(x \times x)\end{array}$ & $\begin{array}{l}361 \text { shift workers, } \\
240 \text { day workers }\end{array}$ & $5.96 / 5.95$ & . & $1.61 / 1.43$ & . & $\begin{array}{l}\text { S: } 139.7 / 139.7 \text {, } \\
\text { D: } 83.0 / 83.3\end{array}$ & . \\
\hline $\begin{array}{l}\text { Lang, } 1988(90) \\
(x x)\end{array}$ & $\begin{array}{l}396 \text { shift workers, } \\
900 \text { day workers }\end{array}$ & . & . & . & . & $\begin{array}{l}\text { S: } 129.7 / 125.3 \\
\text { D: } 75.6 / 74.9\end{array}$ & . \\
\hline $\begin{array}{l}\text { Cesana, } 1990 \\
(57)(x)\end{array}$ & $\begin{array}{l}150 \text { shift workers, } \\
150 \text { day workers }\end{array}$ & 0 & . & 0 & . & . & . \\
\hline $\begin{array}{l}\text { Costa, } 1990 \\
(60)(x)\end{array}$ & $\begin{array}{l}158 \text { shift workers, } \\
44 \text { day workers }\end{array}$ & $5.50 / 5.80$ & $\begin{array}{l}\text { HDL: } 52.6 / \\
53.9\end{array}$ & $149.4 / 144.3$ & . & $\begin{array}{l}\text { S: } 135.0 / 137.5 \\
\text { D: } 89.1 / 86.9\end{array}$ & . \\
\hline $\begin{array}{l}\text { Bursey, } 1990 \\
(74)(x)\end{array}$ & $\begin{array}{l}57 \text { shift workers, } \\
57 \text { day workers }\end{array}$ & $5.68 / 6.19$ & . & . & . & $\begin{array}{l}\text { S: } 125.1 / 124.0 \\
\text { D: } 77.6 / 78.7\end{array}$ & . \\
\hline $\begin{array}{l}\text { Romon, } 1992 \\
(63,88)(x x x)\end{array}$ & $\begin{array}{l}73 \text { shift workers, } \\
73 \text { day workers }\end{array}$ & $5.50 / 5.45$ & HDL:1.21/1.26 & $1.26 / 1.03$ & $\begin{array}{l}\text { ApoA1/B-ratio: } \\
X X 1.21 / 1.32\end{array}$ & $\begin{array}{l}\text { S: } 135 / 134 \\
\text { D: } 85.1 / 86.1\end{array}$ & . \\
\hline $\begin{array}{l}\text { Lasfargues, } \\
1996(58)(x x)\end{array}$ & $\begin{array}{l}1200 \text { shift workers, } \\
1200 \text { day workers }\end{array}$ & $\begin{array}{l}\text { Men: } 5.81 / 5.91 \\
\text { women: } 5.24 / 5.32\end{array}$ & & $\begin{array}{l}\text { Men: } 1.65 / 1.33 \\
\text { women: } 0.9 / 0.8\end{array}$ & . & $\begin{array}{l}\text { Men: S: } 132 / 133 \text {, } \\
\text { D: } 83 / 83 ; \text { women: } \\
\text { S: } 120 / 120, D: \\
78 / 78\end{array}$ & $\begin{array}{l}\text { Leucocytes: } \\
\text { men: } 7.8 / 6.8 \\
\text { women: } 7.6 / 6.6\end{array}$ \\
\hline $\begin{array}{l}\text { Netterstrøm, } \\
1996(85)(x)\end{array}$ & $\begin{array}{l}68 \text { shift workers, } \\
1079 \text { day workers }\end{array}$ & 0 & . & . & . & 0 & $\begin{array}{l}\text { Fibrinogen: } \\
2.88 / 2.66\end{array}$ \\
\hline $\begin{array}{l}\text { Nakamura, } \\
1997(64)(x x x)\end{array}$ & $\begin{array}{l}33 \text { shift workers, } \\
239 \text { day workers }\end{array}$ & $5.70 / 4.98$ & . & $1.70 / 1.58$ & . & $\begin{array}{l}\text { S: } 127.5 / 129.4 \\
\text { D: } 76.7 / 75.5\end{array}$ & . \\
\hline $\begin{array}{l}\text { Bøggild, } 1998 \\
(22)(x x)\end{array}$ & $\begin{array}{l}1123 \text { shift workers, } \\
4084 \text { day workers }\end{array}$ & . & . & . & . & $\begin{array}{l}\text { S: } 136 / 135 \\
\text { D: } 83 / 83\end{array}$ & . \\
\hline \multicolumn{8}{|c|}{ Prospective and cohort studies } \\
\hline $\begin{array}{l}\text { Theorell, } 1976 \\
(68)(x x x)\end{array}$ & $\begin{array}{l}33 \text { shift workers, } \\
\text { own referents } \\
\text { day/night shift; } \\
\text { relative changes }\end{array}$ & $0.96 / 1.02$ & . & . & . & . & $\begin{array}{l}\text { Total lipids: } \\
0.96 / 1.03\end{array}$ \\
\hline $\begin{array}{l}\text { Peacock, } 1983 \\
(91)(x x x)\end{array}$ & $\begin{array}{l}75 \text { shift workers, } \\
\text { own referents }\end{array}$ & & . & . & . & S:O, D:- & . \\
\hline $\begin{array}{l}\text { Orth-Gomér, } \\
1983(65)(x x x) \\
\text { (from figure) }\end{array}$ & $\begin{array}{l}46 \text { shift workers, } \\
\text { clockwise/ counter- } \\
\text { clockwise rotation }\end{array}$ & $-4 /-6^{b}$ & . & $-4 / 15^{\natural}$ & . & $\begin{array}{l}\text { S: } 111.6 / 115.6 \\
\text { D: } 75.2 / 75.8\end{array}$ & . \\
\hline $\begin{array}{l}\text { Fredén, } 1984 \\
(86)(x)\end{array}$ & 18 shift workers & 0 & HDL: 0 & 0 & . & . & . \\
\hline $\begin{array}{l}\text { Sundberg, } 1987 \\
(93)(x \times x)\end{array}$ & 7 shift workers & 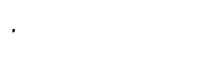 & . & . & . & $24 \mathrm{~h}: 0\left(^{*}\right)$ & . \\
\hline $\begin{array}{l}\text { Chau, } 1989 \\
\text { (94) (xxx) }\end{array}$ & 15 shift workers & 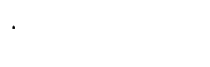 & . & . & . & $24 h:+\left(^{*}\right)$ & . \\
\hline $\begin{array}{l}\text { Baumgart, } 1989 \\
(95)(x x)\end{array}$ & 17 shift workers & . & . & . & . & $24 \mathrm{~h}: 0$ & . \\
\hline $\begin{array}{l}\text { Peternel, } 1990 \\
(89)(x x x)\end{array}$ & $\begin{array}{l}10 \text { shift workers, } \\
10 \text { day workers }\end{array}$ & . & . & . & . & ' & $t-P A l:+\left(^{*}\right)$ \\
\hline $\begin{array}{l}\text { Knutsson, } 1990 \\
(66)(x x)\end{array}$ & $\begin{array}{l}12 \text { shift workers, } \\
13 \text { day workers }\end{array}$ & $5.0 / 4.0$ & . & $1.0 / 1.0$ & $\begin{array}{l}\text { ApoB: } \\
0.84 / 1.03\end{array}$ & $\begin{array}{l}\text { S: } 132 / 124, \\
\text { D: } 71 / 68\end{array}$ & . \\
\hline $\begin{array}{l}\text { Lennernäs, } \\
1994(31)(x x x)\end{array}$ & 22 shift workers & + & Ratio: + & . & . & & . \\
\hline $\begin{array}{l}\text { Kecklund, } 1994 \\
(87)(x x x)\end{array}$ & $\begin{array}{l}60 \text { shift workers, } \\
15 \text { day workers } \\
\text { (before-after) }\end{array}$ & $\begin{array}{l}5.4-5.41 \\
5.4-5.5\end{array}$ & $\begin{array}{l}\text { Ratio: } 3.1- \\
2.7 / 3.2-3.4\end{array}$ & $\begin{array}{l}1.2-1.2 / \\
1.3-1.4\end{array}$ & . & $\begin{array}{l}\text { S: } 132 / 127 \\
\text { D: } 84 / 81\end{array}$ & . \\
\hline
\end{tabular}

averall quality of study, based on Kristensen (2); is given (range from $x$ to $x x x x x$ ).

b Percentage of change. 
Bursey (74) obtained electrocardiograms from day and shift workers and found no differences in the number of normal recordings (68.4\% versus $61.4 \%$ ). One study (34) found a higher number of ventricular extrasystoles in nightshift than in dayshift when the subjects were measured with 24-hour Holter monitoring.

In 5 studies biomarkers for CVD have been evaluated in 24-hour measurements. In one study 24-hour blood pressure was found to shift in parallel but without a change in the mean pressure (93), while another study (94) found a longer plateau with a high diastolic and systolic pressure. A 3rd study on blood pressure found no differences, apart from a phase shift in parallel with the workhours (95), while a 4th (34) found more ventricular extrasystolic beats in shift workers than in day workers. In the 5th study fibrinolytic activity had a lower level in the night shift workers and presumably led to a higher risk of thrombosis (89).

Most studies have thus concentrated on markers of atherosclerosis. Although no firm conclusion can be drawn, both cholesterol and triglycerides seem to be raised, primarily in the methodologically better studies and especially in the few prospective studies. Changes were observed in the predicted direction of higher biomarkers for shift workers in all but 1 study (58).

\section{General methodological problems}

The studies have used very different methodological approaches. Despite the heterogeneity of study design, some problems relate to all studies. One such problem is related to "exposure". There is no commonly accepted definition of shift work, and it encompasses at least 3 different modalities, that of the type of shift work (rotating or fixed, including or excluding night work, continuous or discontinuous, ie, including or excluding weekends), the schedule [number of night shifts in a row, rotating clock- or counterclockwise and other ergonomic criteria for shiftwork scheduling (97)], and the amount of night and evening work (number of night shifts a month). Only a few of the studies have described the work schedule in detail or have included information on the "dose" of exposure, for example, in terms of years of shift work. In the American tradition, the problem of shift work relates to the rotation of work, while Europeans are concerned also with night work in itself $(98,99)$. As a consequence, 2 American studies and 1 European study $(17,48,92)$ included fixed night workers in the reference groups.

The "lifetime" exposure required to be labeled as a shift worker ranges from prevalent self-reported shift work to more than 10 years as a shift worker in the same factory (21). In a subsample of studies, exposure was attached to certain occupations on an aggregated basis, often based on interviews of a smaller sample $(14,16,25$, 100 ). This approach leads to a misclassification of expo- sure, as many of the workers in the exposed occupations were in fact not shift workers and would thus be suspected to give lower risk estimates. This expectation is however not fulfilled. These studies tended to show higher risk estimates than studies with an individual exposure classification.

In some studies shift work takes place in an industrial setting, often comprising $7-8$ nights a month, while others have had the cut off point at 3 shifts (being afternoon or nights) a month (17). Therefore the exposures are generally not comparable, and the exposure in some studies is very weak. Day workers may furthermore be former shift workers; in such cases the exposure contrast between day and shift workers becomes very small (19).

Another issue is the definition of outcome. The epidemiologic studies have used different definitions of CVD and the narrower term ischemic heart disease, and in 1 study also hypotension and varicosis were included (26). Some have dealt only with mortality figures on myocardial infarction, whereas others have also included angina pectoris and myocardial infarction morbidity. Some of the studies have exploited registers of hospital discharges, while others have blindly examined records in order to establish the diagnosis. Strict definitions are only very seldom reported (101), and sudden death is not always included in CVD.

The overall impression is, however, that newer studies have stricter diagnostic criteria. Most studies have combined information on both morbidity and mortality. Two studies $(19,21)$ used only mortality figures. Both of them found no connection between shift work and CVD. As $70 \%$ of myocardial infarction patients survive and as both etiology and personality between survivors and nonsurvivors may differ, it would be advisable to distinguish between these factors in future studies.

Many biochemical factors are subjected to circadian rhythm, among these also several of the biomarkers discussed. In a study of day-oriented healthy subjects, the circadian rhythm attributed to $39 \%$ of the daily variation in triglycerides, the corresponding value being $30-34 \%$ for the total, LDL and HDL cholesterol concentrations, and $11 \%$ for apolipoprotein (102). Thus the timing of blood sampling is important to comparisons of measurements between day and shift workers or between shift workers in different phases of their schedules. If blood samples are drawn immediately after a night shift, the values may be elevated, not due to the effect of shift work, but, instead, because the measurement was done in different phases of the circadian rhythm of the biomarker. Many of the studies reporting on biomarkers do not explicitly state the duration between night work and blood sampling.

We have tried to evaluate the importance of some of these problems for the outcome of the epidemiologic studies. This evaluation involved ranking the studies ac- 
cording to the amount of shift work needed to be included in the shift work group and examining whether this procedure led to a pattern in the outcome. Second, we ranked the studies by diagnostic entity. Third, we ranked by the quality judgment attached to the studies. Neither of these rankings showed any particular pattern in risk estimation, except that the methodologically best studies (labeled xxx and xxxx in table 1) in general show risk estimates of around 1.4 and narrow confidence intervals.

The 4 th problem relates to the selection of comparison groups. The appropriateness of this group is of paramount importance, and the ideal group should resemble the shift workers in all ways (at least regarding risk factors for CVD) than the worktime schedule. In almost all of the studies, the reference groups are not truly comparable in the sense that they are "what the shift workers would be, had they not worked at night".

In many studies it has been problematic to find relevant reference groups, as shift work is often used for only certain functions in a company. Shift work is clearly related to socioeconomic status, as it is more prevalent among unskilled workers and lower civil servants ( 7 , 103). CVD is known to be related to socioeconomic status (104), and therefore socioeconomic status is a potential confounder, especially in studies with the general population as reference. Day-working reference groups may be skilled workers in contrast to unskilled shift workers, and thereby the comparison is done between different socioeconomic groups, with different cultural backgrounds and with differences in life-style. As CVD is known to be more widespread among lower socioeconomic groups, confounding would lead to higher risk estimates. A few epidemiologic studies have controlled for social class, and, in 2 of them, the effect of controlling can be examined. Tenkanen et al (18) analyzed blue-collar day and shift workers alone and found that the relative risks fell. Likewise B $\varnothing$ ggild et al (22) controlled for social class by restricting analyses to 1 social class and found that the risk estimates fell below unity. In the study by McNamee (19) initial job status was controlled for; Kawachi (17) studied only nurses and also controlled for education of spouse; and in the study by Knutsson et al (15) control was made for educational level. In most of the studies, including studies on risk factors, social class differences have not been controlled and may have confounded the results. In contrast, shift workers often earn more or hold a second job.

People choosing to work in shifts are self-selected and are known to differ from day workers in terms of sleeping habits and rigidity of sleep. One study (62) examined whether shift workers differed from day workers in personality traits (type A) that have been linked to CVD (105). This was not found to be the case.

Age is the major risk factor for CVD, and in general shift workers tend to be younger than day workers at the same factories, as day work is, in many instances, a "reward" for some years of shift work. Most epidemiologic studies have controlled for age, but 3 older studies did not $(61,106,107)$, and this omission may explain the "negative" finding of all 3 studies.

Work conditions may differ between shift and day workers in terms of risk factors for CVD (eg, cardiotoxic chemicals, environmental smoke, monotonous or sedentary surveillance work), and may thus act as a confounder for CVD. Only few of the studies report details on work conditions. The direction of this confounding is not predictable, but would probably tend to overestimate the risk. One study found no differences in exposure to environmental smoke between day and shift workers (59).

Day and night work may, for instance, differ in terms of the amount of job strain. Indirectly the importance can be evaluated from the Helsinki Heart Study (18), which provided questionnaire responses about job decision latitude and psychological demands. Comparing these figures for day and 3-shift workers showed that shift workers in "industry work in plant or machine operation" have the same demands but much lower decision latitude than day workers. In another study (15) shift workers experienced more strain than day workers, but control for the differences did not change the risk estimates. In a study of nearly 1000 Swedish subjects engaged in driving, industrial work, police work, or cooking, day-working women experienced higher job strain than shift-working women, while no differences were present for the men (108).

One of the most important methodological problems in shiftwork research is the selection process both into and out of shift work (11). Primary selection into shift work is both due to the applicant and to the company. People applying for shift work may differ from people choosing not to apply, on the basis of the applicants' estimate of their own ability to cope with worktime on the job. Companies may select applicants on the basis of preemployment testing, which may also lead to differences between shift and day workers. This primary selection is uncontrollable, but would probably lead to an underestimation of the true risk.

Secondary selection takes place when the shift worker moves out of shift work. In some instances the move is forced by organizational changes, but it can also be due to medical or social reasons, depending on, for example, feelings of stress, problems with sleep, and the like. These selection processes are probably also of major importance in relation to CVD, as can be seen from ex-shift workers' risk, which is often higher than that of current shift workers $(21,109)$ - Taylor \& Pocock's (21) finding, in their cohort study, was a standardized mortality ratio of 160 (95\% CI 121.5-210.4) (reanalyzed by us). In 1 study sick leaves for CVD among employees 
transferred to day work for medical reasons were more numerous than among shift workers, while transfers due to organizational changes led to the same incidence of sick leaves as that of the day workers (110); this finding suggests that people being at risk of CVD are somehow warned or that causal mechanisms interact with risk factors for other diseases or well-being and lead to selection.

As most of the unaggregated cohort studies $(17,18$, 21,22 ) include subjects in their 40 s, half a worklife may have, in many instances, passed before inclusion, and the selection processes may have played their role. Differences in possibilities for changing work may therefore in part account for the differences found.

The exposure being relatively hard, information bias is probably not very important. In his thesis (30) Knutsson found that a double check between self-stated shift work and personnel records in general showed good agreement between the two. As stated, the exposure in many studies has been measured at one point in time, and, if years of shift work is to be used as an exposure variable, the issue needs to be dealt with.

Many of the reviewed studies have controlled for factors that, in reality, are not confounders, but are instead mediating factors and links in the causal chain between shift work and CVD. This possibility may have led to real differences being hidden.

\section{Discussion}

Seventeen studies dealing with the risk of CVD in people working outside daily workhours were identified. Four large studies did not support a relationship, and, although methodological problems are also present in these studies, the overall quality is not poorer than the majority. On balance, however, the most convincing study (8) demonstrating a dose-response relationship leads to an overall impression that shift work is related to CVD and that shift work increases the risk by about $40 \%$, among both men and women. The apparent heterogeneity of the results may be due to different settings, the ability to find other jobs being a possible explanation. There is, therefore, still a need for epidemiologic studies examining the relationship between shift work and CVD, but the research would have to be more carefully designed.

The causes of the relationship between shift work and CVD have only partly been dealt with. Of 3 suggested major pathways for CVD in shift workers, only 1 pathway has been elucidated in any detail. The literature has focused on life-style changes, and, of these, differences in smoking and diet seem to be important, while alcohol and exercise habits are not. Life-style does not seem to explain more than part of the relationship, however, and one reason for the conflicting results on alcohol, diet, and exercise may be due to these life-style factors also being culture-dependent, a factor that, therefore, leads to shift workers in different countries experiencing different lifestyle changes.

The other pathways, changes in circadian rhythm, and social disruption have received very little attention. The changing circadian rhythm has been dealt with sparsely. It could explain the behavior of biomarkers (higher cholesterol and triglyceride levels), but one cannot exclude a separate importance of, for example, a changed pattern of fibrinogenic activity. The question of social support, stress, and sleepiness has not been studied at all, even though they are both common effects of shift work and also established risk factors for CVD. Future studies would have to look into these areas.

For biomarkers, the focus has been on blood pressure as a marker of sympathic and parasympathic activity. Twenty-four-hour blood pressure may, on the average, be slightly higher for night workers, but not to a degree that reaches hypertension, and not enough to explain a relative risk of 1.4 .

Cholesterol and triglycerides have been studied on several occasions. In the methodologically most convincing studies, shift workers have had slightly elevated values.

Methodological problems are related to the majority of studies, major concerns relating to noncomparable reference groups in terms of social class and different job functions, vague and irrelevant exposure variables, and, especially in early studies, ill-defined outcome variables.

One crucial methodological challenge would be to find suitable reference groups. Much effort should be given to the selection of these groups, as the comparability should be maintained at the highest level. If day workers are used, it would seem to be necessary to control at least for differences in social class (educational level, income, prestige), personality factors (hostility), and the work environment. Another solution would be to include factories in which the use of shift work had been abandoned and follow these former shift workers as referents, as they would probably resemble the shift workers more closely in relation to personality and social class. Selection should be accounted for.

Ideally, studies should incorporate knowledge on the risk factors for CVD and should not control for information on factors that are essential to the mediation of the relationship. The primary risk factors have often been treated as confounders, but they can also, as, for example, tobacco consumption, be higher due to shift work and should be treated as mediating relations and as part of a causal web.

Exposure should be expanded to include fixed night shifts. Three studies have analyzed fixed night work (14, 15,20 ), two suggesting that it confers the same risk as rotating shifts. Different shift schedules should be dis- 
tinguished to identify which type of shift schedule confers the smallest risk. In addition the amount of night work in a shift and the inclusion or exclusion of weekends should be looked into. Of special interest would be to study the impact of ergonomically designed shift schedules that aim at lowering the strain of shift work (97), to investigate whether this change would lower biomarkers for CVD and lead to lower risk of CVD in the long run. The results of intervention studies on risk factors for CVD $(65,87)$ suggest that scheduling can be done in a way that leads to lower risk factors. This is crucial knowledge for primary prevention purposes, but it needs to be expanded.

The traditional 3-shift schedule is increasingly being replaced by flexible worktime arrangements, in which employees are expected to work in more irregular shift systems or with longer workhours. It would be valuable to expand the research to cover these areas, as the irregularity could put further strain on shift workers' social life, depending on the degree of control given to the employee.

Future clinical epidemiologic studies on risk factors in shift workers should include markers of both atherosclerosis and hemostasis, and attention should be paid to the circadian rhythm of the biomarkers. Blood sampling should be made either several times a day, to establish its circadian rhythm, or after several days of day orientation, as the values may reflect different time slots instead of real differences. Intervention studies should be attempted that change the shift schedule and follow the employee during this process.

Two important questions relating to prevention have not been answered: "Is the effect of shift work acute or chronic?" and "Does the effect hit by chance or are people susceptible at the individual level on the basis of biological differences, social life circumstances, or patterns of other risk factors?" In relation to the first, the patterns of myocardial infarction, with a mismatch of oxygen supply and need, could indicate that night work leads to acute effects. In this case it would not be appropriate to study long-term clinical effects, since focus should rather be on the effects of changes in night work on the cardiovascular system in laboratory settings, in studies on people with and those without overt cardiovascular disease. As for the second question, studies on the interaction of risk factors suggest that the answer could be affirmative. Both in the Helsinki Heart Study (111) and in the Swedish SHEEP study powerful interactions between shift work, body mass index, physical activity, and smoking have been found. The implication could be that certain people undergo a large additional risk, while others could be unaffected. This issue of individual susceptibility also needs further enlightening.

The goal of studying shift work and cardiovascular disease should eventually be the ability to prevent dis- ease. No single mechanism seems to be working. Shift workers should probably be advised to maintain healthy life-style habits, especially regarding smoking, and should eat regularly, also on night shifts. Such recommendations concern, however, only part of the issue, as the two other causal mechanisms are not covered (112). A few studies show that the organization of shift work is important; that is, whether the shifts rotate clockwise or counterclockwise (65) and have few or many nights in a row (87) have an explanatory value in themselves on biomarkers of CVD, irrespective of smoking and diet. The impact of this knowledge is potentially of great significance because changes in work organization come closest to helping eliminate exposure.

\section{Acknowledgments}

This work was supported in part by grants from the Danish Heart Foundation (HB) and the Danish Work Environment Foundation ( $\mathrm{HB})$.

\section{References}

1. Beaglehole R. International trends in coronary heart disease mortality, morbidity, and risk factors. Epidemiol Rev $1990 ; 12: 1-15$.

2. Kristensen TS. Cardiovascular diseases and the work environment: a critical review of the epidemiologic literature on nonchemical factors. Scand J Work Environ Health 1989; 15:165-79.

3. Kristensen TS. Cardiovascular diseases and the work environment: a critical review of the epidemiologic literature on chemical factors. Scand J Work Environ Health 1989; 15:245-64.

4. Rose G. Sick individuals and sick populations. Int J Epidemiol $1985 ; 14: 32-8$.

5. Olsen O, Kristensen TS. Impact of work environment on cardiovascular diseases in Denmark. J Epidemiol Community Health 1991;45:4-10.

6. Wedderburn A. Statistics and news: BEST 6. Luxemburg: European Foundation for the Improvement of Living and Working Conditions, 1993.

7. US Congress Office of Technology Assessment. Biological rhythms implications for the worker. Washington DC: US Government printing office, 1991. OTA-BA-463.

8. Knutsson A, Åkerstedt T, Jonsson BG, Orth-Gomér K. Increased risk of ischaemic heart disease in shift workers. Lancet 1986;2(8498):89-92.

9. Kristensen TS. Cardiovascular diseases and the work environment. In: Cheremisinoff PN, editor. Encyclopedia of environmental control technology. 7th ed. Houston (TX): Gulf Publishing Company, 1994:217-43.

10. Akerstedt T, Knutsson A, Alfredsson L, Theorell T. Shift work and cardiovascular disease. Scand J Work Environ Health 1984;10:409-14.

11. Orth-Gomér K. Cardiovascular disease - factors of impor- 
tance in shift workers. Stockholm: Arbetarskyddsverket, 1985:57—63. Arbete och hälsa 1985;27.

12. Wagner U. Schichtarbeit und ischämische herzkrankheit [Shift work and ischemic heart disease]. Z Arztl Fortbild (Jena) 1989;83:229-33.

13. Aanonsen A. Shift work and health. Copenhagen: Scandinavian University Books, Munksgaard, 1964.

14. Tüchsen F. Working hours and ischaemic heart diseases in Danish men; a 4-year cohort study of hospitalization. Int J Epidemiol 1993;22:215-21.

15. Knutsson A, Hallqvist J, Reuterwall C, Theorell T, Åkerstedt T. Shift work and myocardial infarction: a case-control study. Occup Environ Med. In press.

16. Åkerstedt T, Alfredsson L, Theorell T. Arbetstid och sjukdom - en studie med aggregerade data [Work hours and disease - an analysis with aggregated data]. Stockholm: Statens Institut för Psykosocial Miljömedicin, 1987. Stressforskningsrapport, no 190.

17. Kawachi I, Colditz GA, Stampfer MJ, Willett WC, Manson JE, Speizer FE, et al. Prospective study of shift work and risk of coronary heart disease in women. Circulation $1995 ; 92: 3178-82$

18. Tenkanen L, Sjöblom T, Kalimo R, Alikoski T, Härmä M. Shift work, occupation and coronary heart disease over 6 years of follow up in the Helsinki Heart Study. Scand J Work Environ Health 1997;23:257-65.

19. McNamee R, Binks K, Jones S, Faulkner D, Slovak A, Cherry NM. Shiftwork and mortality from ischaemic heart disease. Occup Environ Med 1996;53:367-73.

20. Steenland K, Fine L. Shift work, shift change, and risk of death from heart disease at work. Am J Ind Med 1996:29:278-81.

21. Taylor PJ, Pocock SJ. Mortality of shift and day workers 1956-68. Br J Ind Med 1972;29:201-7.

22. Bøggild H, Suadicani P, Hein HO, Gyntelberg F. Shift work and ischeamic heart disease -22 year follow up in a cohort of middle-aged and elderly men [abstract]. In: Occupational Health \& Rehabilitation Insititue. The second international conference on work environment and cardiovascular diseases, Tel-Aviv, Israel, March 22-25 1998. Ra'anana (Israel): Occupational Health \& Rehabilitation Insititue, 1998:12.

23. Khaw KT, Barrett-Connor E. Sex differences, hormones, and coronary heart disease. In: Marmot M, Elliott P, editors. Coronary heart disease epidemiology: from aetiology to public health. Oxford: Oxford University Press, 1992: 274—86.

24. Reinberg AE, Smolensky MH. Night and shift work and transmeridian and space flights. In: Touitou Y, Haus E, editors. Biologic rhythm in clinical and laboratory medicine. Berlin: Springer Verlag, 1992: 243-55.

25. Alfredsson L, Spetz C, Theorell T. Type of occupation and near-future hospitalization for myocardial infarction and some other diagnoses. Int J Epidemiol 1985;14:378 — 88.

26. Koller M. Health risks related to shift work. Int Arch Occup Environ Health 1983;53:59-75.

27. Epstein FH, Kannel B, Klimov N, Meade TW. Relation of risk factors to clinical events. In: Olsson AG, editor. Atherosclerosis: biology and clinical science. Edinburgh: Churchill Livingstone, 1987:381-8.

28. Hopkins PN, Williams RR. A survey of 246 suggested coronary risk factors. Atherosclerosis 1981;40:1-52.

29. WHO scientific group on cardiovascular disease risk factors. Cardiovascular disease risk factors: new areas for research. Geneva: World Health Organization (WHO), 1994.

30. Knutsson A. Shift work and coronary heart disease. Scand J
Soc Med Suppl 1989;44:1-36.

31. Lennernäs M, Åkerstedt T, Hambræus L. Nocturnal eating and serum cholesterol of three-shift workers. Scand J Work Environ Health 1994;20:401-6.

32. Willich SN, Lowel H, Lewis M, Hormann A, Arntz HR, Keil U. Weekly variation of acute myocardial infarction. Increased Monday risk in the working population. Circulation 1994;90:87-93.

33. Muller JE, Stone PH, Turi ZG, Rutherford JD, Czeisler CA, Parker $\mathrm{C}$, et al. Circadian variation in the frequency of onset of acute myocardial infarction. $N$ Engl $J$ Med 1985;313:1315-22.

34. Härenstam A, Theorell T, Orth-Gomér K, Palm U-B, Unden AL. Shift work, decision latitude and ventricular ectopic activity: a study of 24-hour electrocardiograms in Swedish prison personnel. Work Stress 1987;1:341—50.

35. Åkerstedt T. Sleepiness as a consequence of shift work. Sleep $1988 ; 11: 17-34$.

36. National Heart Lung and Blood Institute Working Group on Sleep Apnea. Sleep apnea: is your patient at risk? Am Fam Physician 1996;53:247-53.

37. Appels A, Mulder P. Fatigue and heart disease. The association between "vital exhaustion" and past, present and future coronary heart disease. J Psychosom Res 1989;33:727-38.

38. Appels A, Falger PR, Schouten EG. Vital exhaustion as risk indicator for myocardial infarction in women. J Psychosom Res 1993;37:881-90.

39. Rosch PJ. Stress and sleep: some startling and sobering statistics [editorial]. Stress Med 1996;12:207-10.

40. Orth-Gomér K. International epidemiological evidence for a relationship between social support and cardiovascular disease. In: Shumaker SA, Czajkowski SM, editors. Social support and cardiovascular disease. New York (NY): Plenum Press, 1994:97-117.

41. Lazarus RS, Folkman S. Stress, appraisal, and coping. New York (NY): Springer Publishing Company, 1984.

42. Brindley DN, McCann BS, Niaura R, Stoney CM, Suarez EC. Stress and lipoprotein metabolism: modulators and mechanisms. Metabolism 1993;42 supp11:3-15.

43. Theorell T, Karasek R. Current issues relating to psychosocial job strain and cardiovascular disease research. J Occup Health Psychol 1996;1:9-26.

44. Siegrist J. Adverse health effects of high-effort/low-reward conditions. J Occup Health Psychol 1996;1:27-41.

45. Barton J, Folkard $\mathrm{S}$. The response of day and night nurses to their work schedules. J Occup Psychol 1991;64:207-18.

46. Monk TH. Coping with the stress of shift work. Work Stress 1988:2:169-72.

47. Frese M, Semmer N. Shiftwork, stress, and psychosomatic complaints: a comparison between workers in different shiftwork schedules, non- shiftworkers, and former shiftworkers. Ergonomics 1986;29:99-114.

48. Gordon NP, Cleary PD, Parker CE, Czeisler CA. The prevalence and health impact of shiftwork. Am J Public Health 1986;76:1225-8

49. Borjanovic S. The influence of shift work on variability of physiological functions. Stockholm, Arbetarskyddsverket, 1985. Arbete och hälsa 27:1985.

50. Scott AJ, Ladou J. Shiftwork: effects on sleep and health with recommendations for medical surveillance and screening. In: Scott AJ, editor. Shiftwork. Philadelphia (PA): Hanley \& Belfus Inc, 1990:273-99. Occupational medicine: state of the art reviews, vol 5 .

51. Singer B, Terborg J, Mayer S. Attitudinal, circadian, circum- 
stantial, and subject selection explanations of shiftwork effects on health. J Occup Med 1994;36:66-9.

52. Ely D. Organization of cardiovascular and neurohumoral responses to stress: implications for health and disease. Ann N Y Acad Sci 1995;771:594-608.

53. Cesana G, Panza G, Ferrario M, Zanettini R, Arnoldi M, Grieco A. Can glycosylated hemoglobin be a job stress parameter? J Occup Med 1985;27:357—60

54. Thelle DS, Forde OH, Try K, Lehmann EH. The Tromso heart study. Acta Med Scand 1976;200:107-18.

55. Knutsson A, Åkerstedt T, Jonsson BG. Prevalence of risk factors for coronary artery disease among day and shift workers. Scand J Work Environ Health 1988;14:317-21.

56. Knutsson A. Relationships between serum triglycerides and g-glutamyltransferase among shift and day workers. J Int Med 1989;226:337-9.

57. Cesana G, Finotte S, De Vito G. CHD risk factors prevalence in middle aged shift workers. In: Costa G, Cesana G, Kogi K, Wedderburn A, editors. Shiftwork: health, sleep and performance. Frankfurt am Main: Peter Lang, 1990:362.

58. Lasfargues G, Vol S, Cacès E, Clésiau HL, Lecomte P, Tichet $J$. Relation among night work, dietary habits, biological measures, and health status. Int J Behav Med 1996;3:123 - 34.

59. Knutsson A, Nilsson T. Tobacco use and exposure to environmental tobacco smoke in relation to certain work characteristics. Scand J Soc Med 1998;26:183-9.

60. Costa G, Betta A, Uber D, Alexopoulos C. Estimate of coronary risk in a group of italian shiftworkers. In: Costa $G$, Cesana G, Kogi K, Wedderburn A, editors. Shiftwork: health, sleep and performance. Frankfurt am Main: Peter Lang, 1990:363-9.

61. Michel-Briand C, Chopard JL, Guiot A, Paulmier M, Studer $G$. The pathological consequences of shift work in retired workers. In: Reinberg A, Vieux N, Andlauer P, editors. Night and shift work: biological and social aspects. Oxford (UK): Pergamon Press, 1980:399-407.

62. De Backer G, Kornitzer M, Dramaix M, Peeters H, Kittel F. Irregular working hours and lipid levels in men. In: Schling $\mathrm{G}$, Mörl H, editors. Expanding horizons in atherosclerosis research. Berlin: Springer Verlag, 1987:217-24.

63. Romon M, Nuttens MC, Fievet C, Pot P, Bard JM, Furon D. Increased triglyceride levels in shift workers. Am J Med 1992;93:259-62.

64. Nakamura K, Shimai S, Kikuchi S, Tominaga K, Takahashi $\mathrm{H}$, Takana $\mathrm{M}$, et al. Shift work and risk factors for coronary heart disease in Japanese blue-collar workers: serum lipids and anthropometric characteristics. Occup Med 1997;47:142-6.

65. Orth-Gomér K. Intervention on coronary risk factors by adapting a shift work schedule to biologic rhythmicity. Psychosom Med 1983:45:407-15.

66. Knutsson A, Andersson H, Berglund U. Serum lipoproteins in day and shift workers: a prospective study. $\mathrm{Br} \mathrm{J}$ Ind Med $1990 ; 47: 132-4$.

67. Rimm EB, Klasky A, Grobbee D, Stampfer MJ. Review of moderate alcohol consumption and reduced risk of coronary heart disease: is the effect due to beer, vine, or spirits. BMJ 1996;312:731-6.

68. Theorel T, Åkerstedt T. Day and night work: changes in cholesterol, uric acid, glucose and potassium in serum and in circadian patterns of urinary catecholamine excretion. Acta Med Scand 1976;200:47-53.

69. Ulbricht TLV, Southgate DAT. Coronary heart disease: seven dietary factors. Lancet 1991;338:985-92.
70. Lennernäs MA-C. Nutrition and shift work: the effect of work hours on dietary intake, meal patterns and nutritional status parameters [dissertation]. Uppsala: Acta Universitatis Upsaliensis, 1993.

71. Lennernäs AC, Andersson A, Hambræus L. Nutrient intake and dietary patterns among male shiftworkers in sweden. In: Costa G, Cesana G, Kogi K, Wedderburn A, editors. Shiftwork: health, sleep and performance. Frankfurt am Main: Peter Lang, 1990:386-91.

72. Paffenbarger RS, Hyde RT, Wing AL, Lee IM, Jung DL, Kampert JB. The association of changes in physical activity level and other lifestyle characteristics with mortality among men. N Engl J Med 1993;328:538-45.

73. Jung RT. Obesity as a disease. Br Med Bull 1997;53:30721

74. Bursey RG. A cardiovascular study of shift workers with respect to coronary artery disease risk factor prevalence. J Soc Occup Med 1990;40:65-7.

75. Jespersen J, Munkvad S, Gram JB. The fibrinolysis and coagulation systems in ischaemic heart disease - risk markers and their relation to metabolic dysfunction of the arterial intima. Dan Med Bull 1993;40:495-502.

76. Hulka BS. Overview of biological markers. In: Hulka BS, Wilcosky TC, Griffith JD, editors. Biological markers in epidemiology. New York (NY): Oxford University Press, 1990:3-15.

77. Manson JE, Tosteson H, Satterfield S, Hebert P, O'Connor GT, Buring JE, et al. The primary prevention of myocardial infarction. N Engl J Med 1992;326:1406-16.

78. Thelle DS. The relative importance of blood lipids and other atherosclerosis risk factors. Eur Heart J 1992;13:29—33.

79. Møller L, Kristensen TS. Plasma fibrinogen and ischemic heart disease risk factors. Arterioscler Thrombz 1991;11:344-50.

80. Meade TW, Ruddock V, Stirling Y, Chakrabarti R, Miller GJ Fibrinolytic activity, clotting factors, and long-term incidence of ischaemic heart disease in the Northwick Park Heart Study. Lancet 1993;342:1076-9.

81. Segal A. Hypertriglyceridaemia and vascular risk - report of a meeting of physicians and scientists, University College London Medical School. Lancet 1993;342:781-7.

82. Kelly S, Hertzman C, Daniels M. Searching for the biological pathways between stress and health. Ann Rev Public Health 1997; 18:437-62.

83. Netterstrøm B, Danborg L, Olesen H. Glycated hemoglobin (HbAlC) as a measure of jobstress. Behav Med 1988;14:136.

84. Singer DE, Nathan DM, Anderson KM, Wilson PW, Evans JC. Association of $\mathrm{HbA} 1 \mathrm{c}$ with prevalent cardiovascular disease in the original cohort of the Framingham Heart Study. Diabetes 1992;41:202-8.

85. Netterstrøm B, Kristensen TS, Møller L, Jensen G, Schnohr P. Psykisk arbejdsmiljø og helbred [Psychosocial work environment and health]. København: Arbejdsmiljøfondet, 1996.

86. Fréden K, Olsson IL, Orth-Gomér K, Åkerstedt T. Effekten på sömn, vagbesvär och kardiovaskulära riskfaktorer av övergang från moturs till medurs skiftrotation hos poliser [Effects on health and well-being of a change to clock-wise shift rotation in a group of policemen]. Stockholm: Statens Institut for Psykosocial Miljömedicin, 1984. Stressforskningsrappporter, no 175.

87. Kecklund G, Åkerstedt T, Göranson B, Söderberg K. Omläggning av skiftschema: konsekvenser för välbefinnande, hälsa, sömn/vakenhet och arbetstrivsel: resultatrapport 2: fråge- 
formulär, dagbok och hälsoundersökning [Changing shift schedule: effects on well-being, health, sleep/wake behaviour and work satisfaction: report of results 2: questionnaire, diary data and health examiniation]. Stockholm: Statens Institut for Psykosocial Miljömedicin, 1994. Stressforskningsrappporter, no 242.

88. Romon M, Grabiaud MH, Nuttens MC, Fievet C, Bar JM, Pot $\mathrm{Ph}$, et al. Plasma lipids and shift work. In: Costa G, Cesana G, Kogi K, editors. Shiftwork: health, sleep and performance. Frankfurt am Main: Peter Lang, 1990: 399-404.

89. Peternel P, Stegnar M, Salobir U, Salobir B, Keber D, Vene N. Shift work and circadian rhythm of blood fibrinolytic parameters. Fibrinolysis 1990;4 suppl:113-5.

90. Lang T, Pariente P, Salem G, Tap D. Social, professional conditions and arterial hypertension: an epidemiological study in Dakar, Senegal. J Hypertens 1988;6:271-6.

91. Peacock B, Glube R, Miller M, Clune P. Police officers' response to 8 and 12 hour shift schedules. Ergonomics 1983;26:479-93.

92. Fouriaud C, Jacquinet-Salord MC, Degoulet P, Aimé F, Lang $T$, Laprunge $J$, et al. Influence of socioprofessional conditions on blood pressure levels and hypertension control. Am J Epidemiol 1984;120:72-86.

93. Sundberg S, Kohvakka A, Gordin A. Rapid reversal of circadian blood pressure rhythm in shift workers. J Hypertension 1988;6:393-6.

94. Chau NP, Mallion JM, Gaudemaris Rd, Ruche E, Siche JP, Pelen $\mathrm{O}$, et al. Twenty-four-hour ambulatory blood pressure in shift workers. Circulation 1989;80:341-7.

95. Baumgart P, Walger P, Fuchs G, Eiff MV, Vetter H, Rahn $\mathrm{KH}$. Diurnal variations of blood pressure in shift workers during day and night shifts. Int Arch Occup Environ Health 1989;61:463-6.

96. Wagner U. Schichtarbeit und hypertonie [Shift work and hypertension]. Z Arztl Fortbild (Jena) 1991;84:191-3.

97. Knauth P. Designing better shift systems. Appl Ergon 1996;27:39-44.

98. Wilkinson RT. How fast should the night shift rotate? Ergonomics 1992;35:1425-46.

99. Wedderburn A. How fast should the night shift rotate? A rejoinder. Ergonomics 1992;35:1447—51.
100. Alfredsson L, Karasek R, Theorell T. Myocardial infarction risk and psychosocial work environment: an analysis of the male swedish work force. Soc Sci Med 1982;16:463-7.

101. Fraser GE. Defining ischemic heart disease syndromes. In: Fraser GE, editor. Preventive cardiology. Oxford: Oxford University Press, 1986:23-7.

102. Rivera-Coll A, Funtes-Arderiu L, Diez-Noguera A. Circadian rhythmic variation in serum concentrations of clinically important lipids. Clin Chem 1994;40:1549-53.

103. Nord-Larsen M, Ørhede E, Nielsen J, Burr H. Lønmodtagernes arbejdsmiljø 1990 [Work environment of employees, 1990]. København: Arbejdsmiljøfondet, 1992.

104. Syme SL. Social class and cardiovascular disease. In: OrthGomér K, Schneiderman N, editors. Behavioral medicine approaches to cardiovascular disease prevention. Mahwah: Lawrence Erlbaum Associates, 1996:43-50.

105. Suls J, Wan CK. The relationship between trait hostility and cardiovascular reactivity: a quantitative review and analysis. Psychophysiology 1993;30:615-26.

106. Thiis-Evensen E. Skiftarbeid og helse [Shift-work and health]. Porsgrunn: Andreas Jakobsens boktrykkeri, 1949.

107. Angersbach D, Knauth P, Loskant H, Karvonen MJ, Undeutsch K, Rutenfranz J. A retrospective cohort study comparing complaints and diseases in day and shift workers. Int Arch Occup Environ Health 1980;45:127-40.

108. Knutsson A, Nilsson T. Job strain in shift and daytime workers. Int J Occup Environ Health 1997;3 suppl 2:s78-s81

109. Koller M, Kundi M, Cervinka R. Field studies of shift work at an Austrian oil refinery. I: health and psychosocial wellbeing of workers who drop out of shiftwork. Ergonomics 1978;21:835-47.

110. Thiis-Evensen E. Skiftarbeid og helse - II [Shift-work and health - II]. Porsgrunn: Norsk Hydro, 1956.

111. Tenkanen L, Sjöblom T, Härmä M. Joint effect of shift work and adverse life-style factors on the risk of coronary heart disease. Scand J Work Environ Health 1998;24:272-8.

112. Koller M. Occupational health services for shift and night workers. Appl Ergon 1996;27:31-7.

Received for publication: 10 September 1998 